\title{
ディスク泳動法による魚類および海生動物の アルドラーゼの分析*
}

\author{
竹 尾 和 典**
}

\begin{abstract}
Summary
Using the method of staining aldolase activity in disc electrophoresis gels, ${ }^{5}$ ) it was demonstrated that the muscle and liver extracts of various fishes and other marine animals contained isozymes of aldolase.

Young yellowtail Seriola quinqueradiata Temminck et SCHLEGEL, flatfish Microstoma kitaharai JoRdAN et Starks, swellfish Fugu pardale Temminck et Schlegel, and sea bream Sebastes matsubarai HILGENDORF, contained in their muscle and liver extracts 2, 3, 5, and 5 aldolase isozymes, respectively.

In muscle extracts of prawn Penaeus japonicus BATE, 3 aldolase isozymes were separated. In muscle extracts of Squilla oratoria de HAAN and of sphincter muscle extract of Atrina pectinata LinNÉ, aldolase activity was contained in a single fraction. In the mantle extracts of cuttlefish Sthenoteuthis bartrami LESGUEUR and Octopus vulgaris CUVIER, 3 aldolase isozymes were separated.
\end{abstract}

魚類のアルドラーゼについては現在まで主として筋肉 アルドラーゼ ${ }^{4)}$ に関する研究が行なわれている。しか しこの酵素は不安定であるといわれ ${ }^{1,2)}$, 結晶化には成 功していない方。

われわれは前報5)に扔いてディスク泳動法を用いたア ルドラーゼ染色法を考案したが, 本実験はての方法を用 いて種々の魚類および数種の海生動物の組織抽出液中の アルドラーゼの分布をしらべたものである。多くの魚類

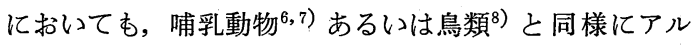
ドラーゼのアイソザイムが存在することを証明しえた。

\section{実験材料および実験方法}

ディスク泳動法 ${ }^{9}$, アルドラーゼ活性測 定法 ${ }^{10)}$, 蛋白 濃度測定法 ${ }^{11)}$, およびアルドラーゼ染色法5) (前報5)の とおりである。

\section{組織抽出液}

魚類は生きた材料を直ちに解体して骨格筋および肝臓 を摘出し, $\mathrm{pH} 7.4$ 亿調整した $1 \mathrm{mM}$ の EDTA 液を組 織量の 2 倍量加えてホモジェナイズし, 3,000 回転 60 分, 次いで 12,000 回転 40 分遠沈して得た上澄を試料とし た。

くるまえび, しゃこは軀幹部の筋肉, たいらぎは閉殼 筋，いか，および，たこ，は外套膜を上と同様に処置し
表 1 各種魚類および海生動物の組織抽出液の アルドラーゼ活性

\begin{tabular}{|c|c|c|c|c|}
\hline 抽 & 液 & $\begin{array}{c}\mathrm{A} \text { 蛋白量 } \\
\mathrm{mg} / \mathrm{m} l\end{array}$ & $\begin{array}{l}\mathrm{B} \text { 活 性 } \\
\Delta \mathrm{E}_{2525} / \mathrm{m} l\end{array}$ & $\underset{\mathrm{B} / \mathrm{A}}{\mathrm{C} \text { 比活性 }}$ \\
\hline ぶ & 白色筋 & 16.0 & 250 & 15.8 \\
\hline " & "I & 27 & 230 & 8.4 \\
\hline "I & "I & 36 & 240 & 6.6 \\
\hline "I & 血合筋 & 7.6 & 0.42 & 0.056 \\
\hline " & 肝 臓 & 15.0 & 2.0 & 0.14 \\
\hline ひがんふ & 骨格筋 & 24 & 188 & 7.9 \\
\hline $\begin{array}{l}\text { やなぎむ } \\
\text { がれ }\end{array}$ & II & 14.6 & 108 & 7.4 \\
\hline " & 肝 臓 & 48 & 9.9 & 0,19 \\
\hline あこうだに & 骨格筋 & 18.0 & 52 & 2.9 \\
\hline "I & 肝 臓 & 43 & 12.7 & 0.30 \\
\hline$\tau$ & 骨格筋 & 14.2 & 73 & 5.2 \\
\hline くるまえて & 筋 肉 & 10.4 & 42 & 4.0 \\
\hline L $p$ & "I & 2.7 & 32 & 11.7 \\
\hline たいらる & 閉殼筋 & 4.2 & 4.8 & 1.15 \\
\hline ばかいカ & 外套膜 & 10.0 & 25 & 2.5 \\
\hline まだ こ & "I & 3.9 & 15.7 & 4.0 \\
\hline
\end{tabular}

て得た $1 \mathrm{mM}$ EDTA 抽出液である。乙れらの試料液は 凍結して貯えると約 1 週間は泳動像にほとんど変化をき たすととなく保存するととができる。

\footnotetext{
* Studies on aldolases of fishes and other marine animals by disc electrophoresis.

**Kazusuke Takeo, 山口大学医学部生化学教室
} 
表 1 亿各種魚類扰よび海生動物の組織抽出液中のアル ドラーゼ活性と蛋白濃度を示した

\section{実 験 結 果}

\section{1: ぶり, (Seriola quinqueradiata Temminck} et Schlegel)

ぶり，の骨格筋には白色の骨格筋とミオシン様の色素 蛋白に富むといわれる赤色の血合筋とが存在する。白色 筋の抽出液の活性は表 1 亿示したように抽出蛋白濃度の 高低にかかおらずほぼ同じ価を示している。てれはアル ドラーゼが抽出されやすい蛋白であるためと考えられ る。そのうち最屯高い比活性を示した抽出液はうさぎ骨 格筋抽出液のアルドラーゼの比活性 ${ }^{5}$ の約 3 倍の値を示 す1例であったが，抽出液の単位容積あたりの活性はか えって低く約 $2 / 3$ であった。

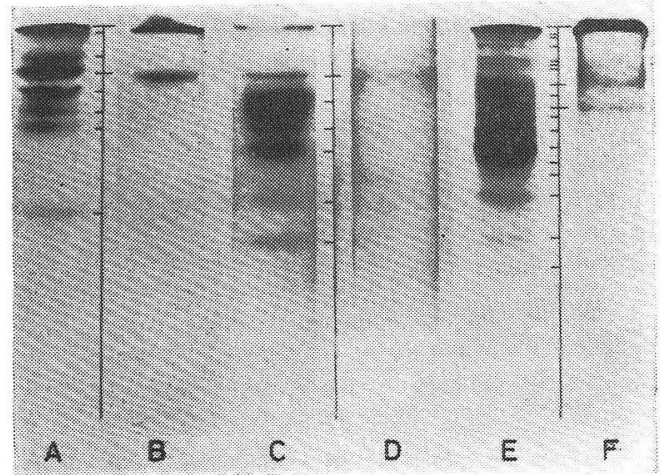

図 1 ぶりの筋肉および肝藏抽出液のデイスク 泳動像とアルドラーゼ活性染色像

$\mathrm{A}$; 白色筋抽出液の蛋白分画像之

B ; そのアルドラーゼ活性染色像。

C; 血合筋抽出液の蛋白分画像之,

$\mathrm{D}$ ；そのアルドラーゼ活性染色像。

$\mathbf{E}$; 肝藏抽出液の蛋白分画像上,

$\mathrm{F}$; そのアルドラーゼ活性染色像。

泳動条件：アクリルアミド，7.5\%，200

Volt, 1.5 時間。

活性染色時間： B ; $30^{\circ} \mathrm{C}, 20$ 分,

$\mathrm{D} ; 30^{\circ} \mathrm{C}, 2$ 時間, $\mathrm{F} ; 30^{\circ} \mathrm{C}, 50$ 分。

図 1-A，Bはぶり白色筋抽出液中の蛋白質のディス ク泳動像 (A) よアルドラーゼ活性染色像 (B) とを示したも のである。蛋白成分は泳動速度の遅い分画から数えて第 3 および第 4 分画に 2 個の濃度の高い分画亡第 1 , 第 2 , 第 5 , 第 6 分画の 4 個の濃度の低い分画とに分れている がアアルドラーゼ活性は第 3 分画に一致して 1 個だけ証 明される。Kwon, Olcott ${ }^{3)}$ は硫交分画法を用いてまぐろ の筋アルドラーゼを精製し，比活坐がうさぎ等格筋の結
晶アルドラーゼの $60 \%$ に達した標品を得たと報告して いる。われわれの用いたぶり白色筋の抽出液は精製処理 を行なう前に比活性がすでにうさぎ筋結晶アルドラーゼ の約 30\% に達している（表 1 ）。一方その泳動像のデン ジトメトリーによりアルドラーゼ分画の相対濃度は約 $30 \%$ であるから，屯し魚類一般の筋肉アルドラーゼが うさぎ筇アルドラーゼよりも比活性が低( $2^{3)}$ とすれば, ぶりのアルドラーゼ分画はアルドラーゼ以外の蛋白を含 む余地は少なくなる。しかしこの活性分画は高い乳酸脱 水素酵素作用を有しており単一なアルドラーゼ分画とは 考えられない。

ぶりの血合筋抽出液は表 1 に示したように, アルドラ 一ゼ活性が弱く，白色筋の約 300 分の 1 にすぎない。そ の蛋白泳動像は図 1-C に示したように，白色筋とはか なり異なった像を呈している。すなおち，1つの主成分 を含めて境界の岕まり鮮明でない6 個の分画に分かれ ているが，アルドラーゼ活性（网 1-D）は泳動速度の 1 番遅い分两にだけ認められる。この活性分画の泳動速度 は白色筋のアルドラーゼ分画の泳動速度と等しく，両筋 のアルドラーゼは同一の酵素䨞白であろうと考えられ る。

ぶりの肝臓抽出液中の蛋白質のディスク泳動像とアル ドラーゼ活性染色像を図 1-E と F に示した。蛋白成分 は17 個の分画に分かれ，アルドラーゼ活性は泳動速度 の遅い分画から数えて第 7 分画に一致して見られるが, 第 9 分画にも弱い活性が認められる。この 2 つの活性分

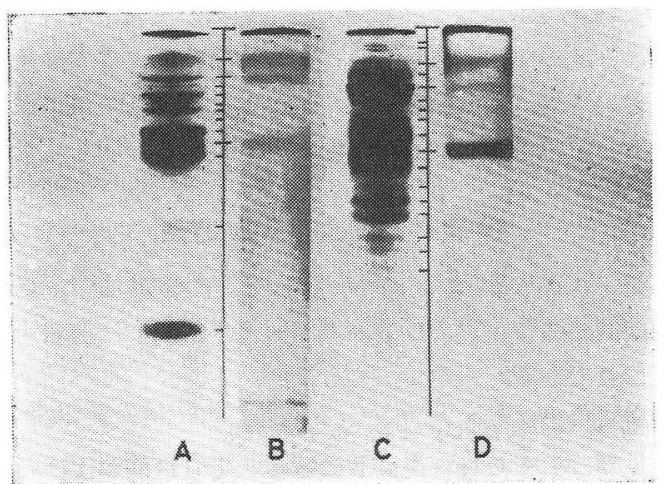

図 2 やなぎむしがれいの筋肉および肝臓抽出 液のデイスク泳動像とアルドラーゼ活性 染色像

$\mathrm{A}$; 骨格筋抽出液の蛋白分画像上,

B ; そのアルドラ一ゼ活性染色像。

C ; 肝臓抽出液の蛋白分画像之,

$\mathrm{D} ;$ そのアルドラーゼ活性染色像。

泳動条件：図1に同じ。

活性染色時間： $B ; 30^{\circ} \mathrm{C}, 40$ 分, $\mathrm{D} ; 30^{\circ} \mathrm{C}$, 1 時間。 
画のうち第 7 分画に認められるアルドラーゼは筋肉抽出 液中のアルドラーゼと泳動速度が等しく, 同じ醉素蛋白 であろうと考えられる。

\section{2：やなぎむしがれい (Microstoma kitaharae Jordan et Starks)}

図 2-A, B にかれいの筋肉抽出液中の蛋白質のディス ク泳動像 (A) とアルドラーゼ活性染色像 (B) とを示した。 蛋白成分は 12 分画に分かれ, アルドラーゼ活性は泳 動速度の遅い分画加ら数えて第 1 , 第 2 , 第 9 分画に一 致して 3 カ所に認められる。図2-C, D は同じかれいの 肝臓抽出液中の蛋白質のディスク泳動像 (C) とアルドラ 一ゼ活性の染色像 (D) とを示したむのである。蛋白成分 は 17 個の分画に分かれ,アルドラーゼ活性は第 3 ，第 5 , 第 10 分画に証明されるが, 第 10 分画の活性が最む高 い。肝臓抽出液中に現われるこれら 3 つの活性分画は泳 動的には筋肉抽出液中に存存玄る 3 つの活性分画上それ ぞれ等しいすのと考えられる。

3 : ひがんふぐ (Spheroides pardale Temminck et Schlegel)

図 3-A，B はひがんふぐの筋肉抽出液中の蛋白質のデ ィスク泳動像 (A) とアルドラーゼ活性の染色像 (B) を示し たものである。蛋白成分は約 10 個の分画に分かれ，ア ルドラーゼ活性は泳動速度の遅い分画から数えて第 4 分 画に一致して強く出現しているが，第 2 , 第 10 分画に 屯弱い活性を示す。

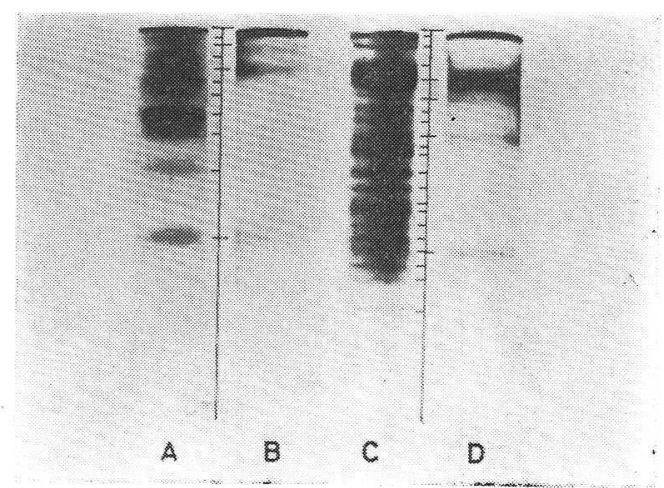

図 3 ひがんふぐの骨格筋および肝藏抽出液の デイスク泳動像とアルドラーゼ活性染色 像

$\mathrm{A}$; 骨格筋抽出液の蛋白分画像上, B；そのアルドラーゼ活性染色像。

$\mathrm{C}$; 肝臟抽出液の蛋白分画像亡,

D ; そのアルドラーゼ活性染色像。 泳動条件：図 1 亿同じ。

活性染色時間： B； $30^{\circ} \mathrm{C}, 40$ 分, $\mathrm{D} ; 30^{\circ} \mathrm{C}, 1$ 時間。
一方，同じふぐの肝臟抽出液中の蛋白質のディスク泳 動像は図3-C, D に示したように，約 20 個の分画に分 かれ (C), アルドラーゼ活性 (D) は泳動速度の遅い分画か ら数えて第 4 , 第 5 , 第 8 上第 17 の 4 分画に証明される。 この 4 つの活性分画の中で活性の最む高い第 4 分画の泳 動速度は, 筋肉抽出液の活性分画の中で最も活性の高い 分画の泳動速度と等しく，両者は同じ醰素蛋白であろう と考えられる。他方, 肝臟抽出液中の第 17 分画に対応 する活性分画は筋肉抽出液の第 10 分画のアルドラーゼ と同一酵素蛋白であろうと考えられる。

\section{4 : あこうだい (Sebastes matsubarai Hilgendorf)}

図 4-A，B はあこうだいの筋肉抽出液中の蛋白質のデ イスク泳動像 (A) とアルドラーゼ活性の染色像 (B) を示し たむのである。蛋白成分は約 9 個の分画に分かれ，アル ドラーゼ活性は第 4 , 第 6 , 第 8 の 3 分画に出現するが, 第 6 分画の活性が最む高い。

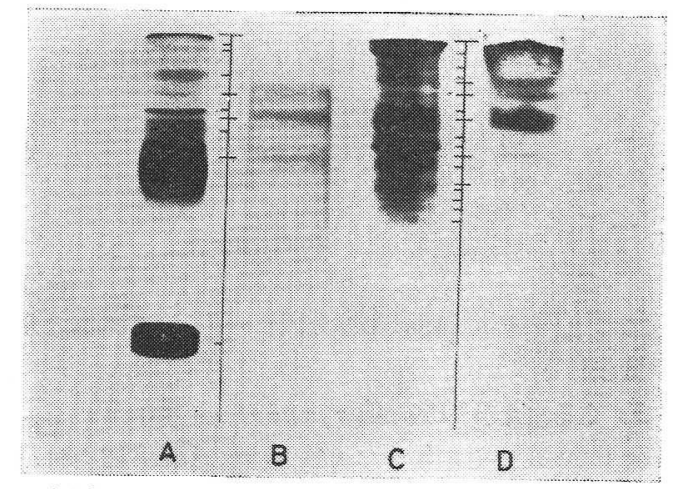

図4 あこうだいの骨格筋および肝臓抽出液の デイスク泳動像とアルドラーゼ活性染色 像

$\mathrm{A}$; 骨格筋抽出液の螢白分画像之, B ; そのアルドラーゼ活性染色像。 $\mathrm{C}$; 肝臓抽出液の蛋白分画像と, $\mathrm{D}$ ；そのアルドラーゼ活性染色像。 泳動条件：図 1 に同じ。 活性染色時間 : $30^{\circ} \mathrm{C}, 30$ 分。

図 4-C, D は同じあこうだいの肝臓抽出液中の蛋白質 のディスク泳動像 (C) とアルドラーゼ活性染色像 (D) とを 示したものである。蛋白成分は約 16 個の分画に分か れている。肝臟抽出液の最も強いアルドラーゼ活性帯は 筋肉抽出液中の主活性分画と泳動速度がほぼ等しい。し かしそれよりも泳動速度の小さい2 個の活性分画（第 4 , 第 5 分画）と, それより泳動速度の大きい 2 個の弱 い活性分画（第 10 ，第 12 分画）が見られる。そのうち 泳動速度の小さい第 4 分画之泳動速度の大きい第 12 分 画を除いて，他の 3 個の活性分画は筋肉抽出液中に見ら 
(182)

生物物理化学

れる 3 個のアルドラーゼ分两とそれぞれ対応する位置に ある。

\section{5 : こい (Cyprinus carpio Linné)}

図 5 はこいの筋肉抽出液中の蛋白質のディスク泳動像 (A) とアルドラーゼ活性の染色像 (B)を示したむのであ る。蛋白成分は約 10 個の分画に分かれ，アルドラーゼ

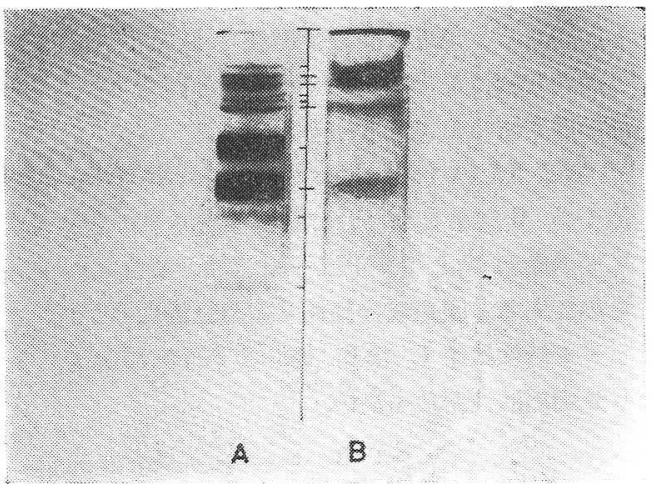

図 5 こい骨格筋抽出液のデイスク泳動像とア ルドラーゼ活性染色像。

A ; 骨格筋抽出液の蛋白分画像,

B ; アルドラーゼ活性染色像。

泳動条件：図 1 亿同じ。

活性染色時間： $30^{\circ} \mathrm{C}, 40$ 分。

活性は第 2 , 第 3 , 第 6 , 第 8 分画に一致して 4 個の分画 が見られる。

\section{6 : くるまえび (Penaeus japonicus Bate)}

図 6-A, B はくるまえびの筋肉抽出液中の蛋白質のデ イスク泳動像 $(\mathrm{A})$ とアルドラーゼ活性の染色像 (B) とを示 したものである。蛋白成分は約 12 個の分画に分かれ， アルドラーゼ活性は泳動速度の遅い分画から数えて第 2，第 4, 第 5 分画に一致して認められる。

\section{7 : しゃこ (Squilla oratoria de Haan)}

図 6-C, D はしゃ乙の筋肉抽出液中の蛋白質のディス ク泳動像 (C) とアルドラーゼの活性染色像 (D) とを示した ものである。蛋白成分は約 10 個の分画に分かれる。ア ルドラーゼ活性は第 3 分画に一致して 1 個だけ証明され る。

\section{8 : たいらぎ (Atrina pectinata Linné)}

図 6-E, F はたいらぎの閉殼筋抽出液中の蛋白質のデ イスク泳動像 (E) とアルドラーゼ活性染色像 (F) とを示し たものである。蛋白成分は約 15 倜の分画に分かれ，ア ルドラーゼ活性は第 5 分画に一致する 1 分画だけに証明 される。

\section{9 : ばかいか (Sthenoteuthis bartrami Lesueur)}

戍 7-A, B はばかいかの外套膜抽出液中の蛋白質のデ

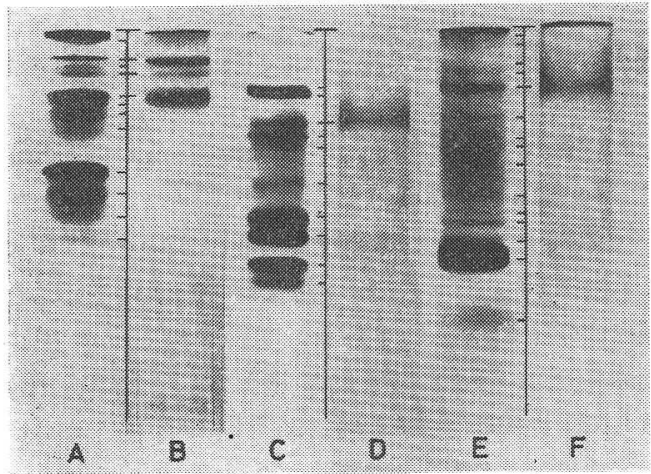

図 6 くるまえび・しゃこ执よびたいらぎの筋肉抽 出液のデイスク泳動像とアルドラーゼ活性染 色像

A ; くるまえび身區幹筋抽出液の蛋白分两像,

B；そのアルドラーゼ活性染色像。

C; Lゃこの軀輳筋抽出液の蛋白分画像と,

D；そのアルドラーゼ活性染色像。

$\mathrm{E} ;$ たいらぎの括約筋抽出液の蛋白分画像と， F ; そのアルドラーゼ活性染色像。 泳動条件：図 1 に同じ。

活性染色時間： $\mathrm{B} ; 30^{\circ} \mathrm{C} ， 30$ 分,

$\mathrm{D} ; 30^{\circ} \mathrm{C}, 30$ 分, $\mathrm{F} ; 30^{\circ} \mathrm{C}, 20$ 分。

イスク泳動像 (A) とアルドラーゼ活性の染色像 (B) とを示 したものである。蛋白成分は約 22 個の分两に分かれて いるが,アルドラーゼ活性は第 12 分画に一致して一つの 主活性分画方現われているほかに, 泳動ゲルの原点に近 く蛋白分画像の不鮮明な場所と第 10 分画の計 3 分画に

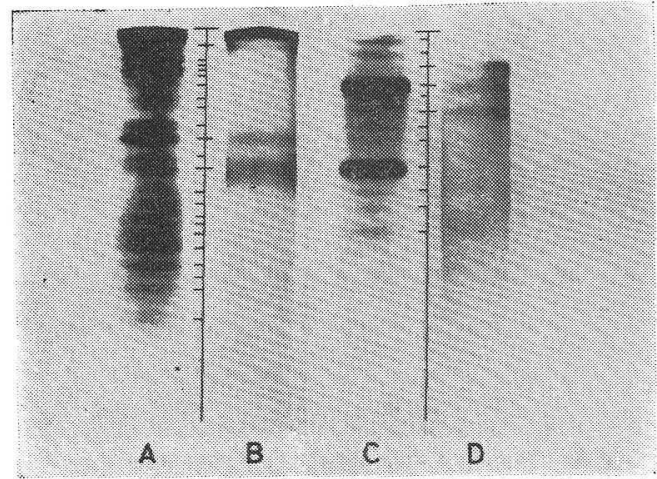

図 7 いか执よびたこの外套膜抽出液のデイス ク泳動像とアルドラーゼ活性染色像

A；认か外套膜抽出液の蛋白分画像と, B；そのアルドラーゼ活性染色像。 C; たこ外套膜抽出液の蛋白分画像と, D；そのアルドラーゼ活性染色像。 泳動条件：図 1 亿同じ。 活性染色時間： B； $30^{\circ} \mathrm{C} ， 40$ 分, $\mathrm{D} ; 30^{\circ} \mathrm{C}, 1$ 時間。 
認められる。

\section{0 : まだこ (Octopus vulgaris Cuvier)}

図 7-C, D はまだての外套膜抽出 液のディスク泳動像 (C) とアルドラーゼ活性の染色像 (D) とを示したあのであ る。蛋白成分は約 12 個の分画に分かれているが第 4 お よび第 9 分画は蛋白濃度が高い。アルドラーゼ活性は第 3 ，第 4, 第 6 分画に一致して 3 個認められる。そのい ずれも泳動的にはたこの外套膜抽出液中のアルドラーゼ とは異なった酵素であろうと考えられる。

\section{考按}

Rutter $ら^{6)}$, Leuthardt $ら^{7)}$ あるいは Kaplan $ら^{8)}$ に よって報告されているように，哺乳動物および鳥類にお いてはアルドラーゼには電気泳動的，免疫学的に区別さ れる臓器特異的な 3 つの型の酵素——筋肉型, 肝蔵型, 脳型—があると考えられている。しかもこれらのアル ドラーゼはそれぞれ 4 個の subunits（副量体）からなる tetramer ( 4 量体) でそれぞれ 2 種類の藏器特異性アル ドラーゼの間の hybridization（混成）によって更に 3 個ずつの hybrids（混成体）の形成されることが知られ ている。他の部門に属する動植物のアルドラーゼについ てはアイソザイムの存在に関する報告はない。

まぐろ筋アルドラーゼ ${ }^{3}$ ，ボア蛇の筋肉アルドラー ゼ12)，ほうれん草アルドラーゼ18,14)，の分子量はうさぎ 筋アルドラーゼの分子量に近く, 更にボア蛇筋アルドラ 一ゼ12)，执よびほうれん草アルドラーゼ14)は3つの活性 中心を有していると報告されている。

ぶりに执いては白色筋，血合筋と屯にその抽出液中に いわゆる筋肉型アルドラーゼと考えられる活性分画のみ を認める。しかし肝臓抽出液中には，筋肉型アルドラー ゼと泳動速度のほぼ等しい主活性分画のほかにそれより やや泳動速度の大きい活性分画が認められる。

かれいの筋肉抽出液中には 3 つのアルドラーゼ分画が 存在し, そのうち泳動速度の最む遅い活性分画が主成分 をなしている。一方，かれいの肝臓抽出液に打いても泳 動的には全く同じ位置に 3 個の活性分画が認められるが, 泳動速度の最む大きい分画が主活性分画をなしている。

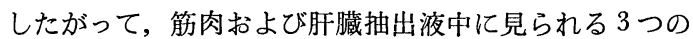
アルドラーゼ分画の中で泳動速度の最む小さいものを筋 肉型, 最も大きい分画を肝蔵型と考えることができよう。 しかし，ぶり肝臓抽出液中に見られる 2 個の活性分画の うち, 泳動速度の小さい分画は泳動速度の点ではかれい の筋肉型アルドラーゼに対応するあのであるが，泳動速 度の大きい分画はかれいの肝藏型アルドラーゼと考えら れる分画に比してはるかに泳動速度が小さい。
ふぐに扎いては筋肉抽出液中に, ぶり, かれいの筋肉 型アルドラーゼと考えられる酵素分画に一致して 1 つの 主活性分画を見るが，それよりも更に泳動速度の小さい 活性分画が 1 個存在する。更にふぐ肝臓抽出液中には 4 個の活性分画を見るが，そのうち泳動速度の最む小さい 分画が主活性分画であり，しかも筋肉抽出液中の主活性 分画と同一のアルドラーゼであると考えられる。したが ってふぐの肝臟抽出液中のアルドラーゼは筋肉型アルド ラーゼと区別できない。

他方，あこうだいに括いては筋肉抽出液中の主活性分 画はかれい，ぶり，あるいはふぐの筋肉アルドラーゼと 考えられる分画よりあ速く泳動しており, 肝臟抽出液の 主活性分画も筋肉抽出液の主活性分画と泳動的に同一で ある。

以上のように, 魚類のアルドラーゼについては哺乳動 物の場合と異なって筋肉抽出液中にもいわゆる筋肉型ア ルドラーゼ以外に数種のアルドラーゼ分画が認められ, 肝藏抽出液においてむ，かれいの場合を除き，いわゆる 肝臓型アルドラーゼというより筋肉型アルドラーゼと電 気泳動的に区別できないアルドラーゼが主成分をなして いる。

松島ら ${ }^{15)}$ はねずみの肝臓癌においては肝臓抽出液中 に肝蔵型アルドラーゼが顕著に減少し, かえって泳動 的, 免疫学的に筋肉型アルドラーゼと考えられるアルド ラーゼが多量に出現して来ると報告している。てれに対 し本実験に用いた魚類に执いては肉眼的には異状を認め ない正常肝抽出液中にいわゆる肝藏型というより筋肉型 と考えられるアルドラーゼがより高濃度に含まれている という結果を示している。

この事実は魚類に执いては, 哺乳動物あるいは鳥類に ついて見られる臓器特異性によるアルドラーゼ・アイソ ザイムの区別を困難にするというほかはない。

\section{要 約}

ポリアクリルアミド・ゲルを支持体とするディスク泳 動法を利用したアルドラーゼ活性の染色同定法を用いて 各種海生動物の組織抽出液中のアルドラーゼの分析を行 ない，ほとんどすべての海生動物にアルドラーゼのアイ ソザイムが存在することを明らかにした。

ぶり，やなぎむしかれい，ふぐ，あこうだいにおい ては筋肉および肝蔵抽出液中にそれぞれ $2,3,5,5$ 種の アルドラーゼ・アイソザイムが含まれていた。こいの筋 肉には 4 個，くるまえび，しゃこ，たいらぎの筋肉抽出 液にはそれぞれ $3,1,1$ 個のアルドラーゼが含まれてい た。たこ，いかの外套膜抽出液にはそれぞれ 3 個のアル 
ドラーゼ・アイソザイムが含まれていた。

魚類の筋肉扰よび肝臟抽出液中に見られる $2 \sim 5$ 種の アルドラーゼは哺乳動物のアルドラーゼと異なり, 臟器 特異性に乏しく，筋肉型と肝臟型アルドラーゼとに区別 することは困難であった。

\section{文献}

1) Connell, J. J.: J. Food Science 31, 313 (1966)

2) Shibata, T.: Bull. Fac. Fish. Univ. Hokkaido 9, 218 (1958)

3) Kwon, T. W. \& Olcott, H. S.: Comp. Biochem. Physiol. 15, 7 (1965)

4) Roberts, E. \& Tsuyuki, H.: Biochim. Biophys. Acta 73, 673 (1963)

5) 竹尾和典 : 生物物理化学 14, 15 (1969)

6) Penhoet E., Rajakumar, T. V. \& Rutter, W. J.: Proc. Natl. Acad. Sci. 56, 1275 (1966)

Penhoet, E., Kochman, M., Valentine, R. \& Rutter, W. J.: Biochemistry 6, 294 (1967)

7) Rensing, U., Schmid, A. \& Leuthardt, F.: HoppeSeyler's Z. Physiol. Chem. 348, 921 (1967)
8) Herskovitz, J. J., Masters, C. J., Wasserman, P. M. \& Kaplan, N. O.: Biochem. Biophys. Res. Commun. 26, 24 (1967)

9) Ornstein, L. \& Davis, B. J.: Preprint by Distillation Product (1962)

10) Swenson, A. D. \& Boyer, P. D.: J. Am. Chem. Soc. 79, 2174 (1957)

11) Gornall, A. G., Bardawill, C. S. \& David, M. M.: J. Biol. Chem. 177, 751 (1949)

Lowry, O. H., Rosebrough, N. J., Farr, A. L. \& Randall, R. J.: J. Biol. Chem. 193, 265 (1951)

12) Schwartz, E. \& Horecker, B. L.: Arch. Biochem. Biophys. 115, 407 (1966)

13) Brooks, K. \& Criddle, R. C.: ibid 117, 650 (1966)

14) Fluri, R., Ramasarana, T. \& Horecker, B. L.: Europ. J. Biochem. 1, 117 (1967)

15. 松島泰次郎, 川辺澄江, 杉村 隆 : 第 39 回日本生 化学会総会 堺市 1967 年 11 月 6 日; 抄録, 生化学 39, p. 527.

Matsushima, T., Kawabe,S., Shibuya, M. \& Sugiura, T.: Biochem. Biophys. Res. Commun. 30, 565 (1968) 